\title{
The Holocaust Is a Significant and Independent Risk Factor of Late-Onset Cancers: A Systematic Review of the Literature and Original Data on Jewish Israeli, Jewish Non-Israeli and Non-Jewish Non-Israeli Survivors
}

\author{
EDOARDO VIRGILIO ${ }^{1,2}$, DANIELE CAMILLI ${ }^{3}$, GIORGIA GILI ${ }^{4}$, FILIPPO MONTALI ${ }^{2,5}$, \\ CARLO SALVEMINI ${ }^{2}$, ALFREDO ANNICCHIARICO ${ }^{1}$, LORENZO PAGLIAI $^{1}$, \\ ANDREA MORINI ${ }^{1}$, ANDREA ROMBOLI $^{6}$ and RENATO COSTI ${ }^{1,2}$ \\ ${ }^{1}$ Department of Medicine and Surgery, University of Parma, Parma, Italy; \\ ${ }^{2}$ Department of General Surgery, di Vaio Hospital, Fidenza, Italy; \\ ${ }^{3}$ Tusciaweb Journal, Viterbo, Italy; \\ ${ }^{4}$ Science for the Conservation and Restoration of Cultural Heritage, Pesaro, Italy; \\ ${ }^{5}$ Department of Experimental Medicine, University of L'Aquila, L'Aquila, Italy; \\ ${ }^{6}$ Department of General Surgery, Guglielmo da Saliceto Hospital, Piacenza, Italy
}

\begin{abstract}
Background/Aim: Seventy-six years after Auschwitz Liberation, the Holocaust keeps on persecuting its surviving victims. As witnessed by the psychiatric and medical literature in the last decades, in fact, the Holocaust survivors (HS) appear to suffer from several Shoah-related late-onset diseases impacting their survival, such as internal illnesses and posttraumatic stress disorder (PTSD). Cancer represents a further severe pathology which seems to be connected with the Holocaust experience. Our aim was to review the existing knowledge of Holocaust-related cancer in HS in order to assess its real incidence and clinicoprognostic significance. Materials and Methods: We systematically reviewed the literature dealing with Israeli Jewish and non-Jewish non-Israeli HS developing cancer. We also reviewed and analyzed the cancer data of noted Jewish HS not resident or having resided in Israel available as public information. Results: We found 16 and 15 studies on Israeli Jews and non-Jewish non-Israeli survivors, respectively.
\end{abstract}

This article is freely accessible online.

Correspondence to: Prof. Edoardo Virgilio, Department of Medicine and Surgery, University of Parma, via Gramsci 14, 43126, Parma, Italy. Tel: +39 0524515605, Fax: +39 0524515267, e-mail: edoardo.virgilio@unipr.it, aresedo1992@yahoo.it

Key Words: Holocaust, Shoah, cancer, colorectal cancer, breast cancer, lung cancer, Nazi doctors, PTSD, review.
A statistically significant association between the Holocaust and development of late-onset cancer in HS was seen in most studies with cancer adversely impacting the survival. We also selected 330 noted Jewish non-Israeli HS: genocide-related late-onset cancer resulted to be a significant and independent risk factor of poor prognosis $(p<0.0001)$ imparting shorter survival in affected versus non-cancer subjects (57 versus 64 years, respectively, $p=0.0001)$. Conclusion: Although 76 years have passed, our review shows how the Holocaust keeps on burdening its survivors. Moreover, we offered the first analysis of Jewish HS not resident or having resided in Israel in terms of genocide-related late-onset diseases focusing on cancer. Further studies on Jewish non-Israeli HS are needed in order to corroborate our findings on late-onset cancer occurring in this targeted population.

The Holocaust undoubtedly represents one of the darkest pages in the history of mankind: still today, European concentration and extermination camps, the ghettos and all the Memorial sites are steeped in horrors and crimes perpetrated by the Nazi Germany (1). Interestingly, differently from other past or current genocides, only the Shoah was characterized by a systematic and dehumanized medicalization of the sufferings $(1,2)$. To the physicians and medical students of today, in fact, it is emotionally and rationally shocking to know that the atrocities inflicted in anus mundi were realized with the active complicity of the German medical community and that, with very few notable exceptions, history has ignored 
such despicable behaviors for about 50 years (1-6). As of 2021, according to the Claims Conference, approximately 400,000 of the 3,586,993 million Jews who were in Europe at the end of the Second World War (WWII) are still alive in the world today (7). Several organizations and local registries scattered throughout the globe estimate that about 197,000 Holocaust survivors (HS) currently reside in Israel, 67,100 in the United States (38,000 only in the New York City Metropolitan Area), 20,000 in Europe, 10,000 in Australia, 5,000 in Canada $(8,9)$. When WWII ended, HS were violated both physically and spiritually showing the so-called "concentration camp syndrome" (9). And after 76 years, now that they in their 80s, 90s and 100s, they continue to suffer from the aftermaths of the Shoah: such a phenomenon has emerged as "late effects of the Holocaust" $(7,8)$. Therefore, investigating the long-lasting effects of the Holocaust on survivors represents a biologically and morally dutiful attempt of research. First studies on HS' health condition commenced in 1957 and initially addressed only the impairments and ailments of their psychological and emotional sphere: this "psychiatric literature" on HS flourished through the years and consists now of a plethora of works where the risk/rate of suicide, the incidence/prevalence of post-traumatic stress disorder (PTSD) and the building of resilience comprise the leading topics more frequently examined (10-12). Most interestingly, it was just from this kind of studies that the information on long-term post-WWII somatic diseases of HS came out: through psychological examinations, in fact, researchers became aware of how HS coped with cardiovascular disorders, endocrine, metabolic and immune dysfunctions, osteoporosis and cancer which were related, at a first sight, only to aging $(13,14)$. Since 1984 the emotional and psychosocial effects of cancer, in particular, appeared to the psychospecialists an interesting problem to explore in HS because felt by them as a stressor very similar to the original trauma of genocide (the same phenomenon is occurring today with COVID-19): both were associated with fear, uncertainty, disfigurement, loss of personal control, social rejection and sense of total helplessness $(12,15)$. The first studies on cancer HS (cHS) were limited to psychological dissertation and wholly lacking in oncologic perspectives; it was only by the end of 2000s that researchers started to rivet a more medical attention to the problem of cancer in HS through analysis of clinicopathological features, morbidity and mortality (16). Digging into the HS literature, our aim was to discover and assess whether the association between the Holocaust and cancer has a real significance in terms of statistical, clinical and prognostic value.

\section{Materials and Methods}

We systematically reviewed the world literature written in English existing on cHS where the words "cancer", "tumor", "Holocaust", "Shoah", "Jewish" and "non-Jewish" were mentioned. Both Jewish and non-Jewish victims were entertained. With this intent, eight popular search engines were investigated (PubMed, MEDLINE, Scopus, Web of Science, Science Direct, Cochrane Library, Google Scholar and Research Gate). Selection of the studies was undertaken following the definition of HS provided by some authors based on country of birth and year of immigration or the one certified by Israeli research and governmental institutions (the Holocaust Survivor Benefits Law) according to which "the HS is a person who lived in one of the countries occupied by or under the influence of the Nazi regime for any length of time between 1933 and 1945; people who were forced to leave their place of residence because of the Third Reich are also included" (17). All the other genocides (such as the Chinese famine of 1958-1961) occurring in the $20^{\text {th }}$ and $21^{\text {st }}$ century were excluded.

After preliminary search, we interestingly observed that, concerning Jewry, the literature studied survivors living only in Israel whereas publications on non-Jewish victims were based out of Israel (mainly Europe). Hence, we decided to investigate and review the knowledge on Jewish HS who do/did not reside in Israel: except for one case report, no dedicated literature exists. Therefore, we canvassed the public domain information (fully accessible and free from any rights) on "noted" HS available through the internet as digitized Memorial Archives, digital Registries, obituaries, death notices and other related material (18-21). To be included in this analysis, a survivor was reckoned "noted" if present in the list of Holocaust Survivors from Wikipedia: spokesmen, speakers, writers, authors, poets, scientists, mathematicians, actors, directors, artists, musicians, sportsmen, politicians, partisans, military men, theologians and rabbis, engineers and economists were the main professions entertained (22). The leading features analyzed for all HS were: years of survival or death from the International Holocaust Remembrance Day (27th January 1945), cause of death (cancer, cardiovascular, pulmonary-COVID19 and psychologicpsychiatric diseases), exposure to extermination, concentration or labor camps (ghettoes were excluded from this category) in Europe.

Statistics. Statistical analysis of data on Jewish non-Israeli HS was performed using MedCalc ${ }^{\circledR}$ Statistical Software version 19.7.2 (MedCalc Software Ltd, Ostend, Belgium; https://www.medcalc.org; 2021). Categorical variables were compared using the Chi-square test, whereas continuous data were compared through the Student's $t$-test. Comparison among groups with cancer, cardiovascular, pulmonaryCOVID19, psychiatric diseases and exposures to Nazi Camps were conducted in terms of mortality: univariate and multivariate analyses (with one-way ANOVA test and logistic regression test) were used to assess significant association and independency, respectively, among variables. Survival curves were created by means of the Kaplan-Meier method and the log-rank test was used to evaluate statistical significance; multivariate analysis of survival was realized with the Cox proportional hazards model. A $p$-value $\leq 0.05$ was considered statistically significant.

\section{Results}

Literature on Jewish Israeli Holocaust Survivors developing late-onset cancer. Papers published on HS come from Israel and include Jewish Israeli survivors only. In fact, differently from other countries (such as USA, Canada and Australia) where many HS settled, in Israel studies on HS were/are more feasible due to the availability of databases with death 
and population records (11). The main features of cHS are listed in Table I $(15,16,23-36)$. We found 16 original studies: 8 were retrospective $(15,16,23,25,33-36), 1$ was half retrospective half cross-sectional (24), while the other 7 analyzed historical cohorts with a prospective investigation (questionnaires or updated follow-ups) (26-32). The first work published in a non-psychological journal dates back to the year 2009 (16); before that, as stated in the introduction section, all the analyses and discussion on cHS subjects were essentially addressed by specialists belonging to the science of the mind and personality who first noted and studied their reaction to the long-term consequences of the Holocaust, including cancer $(15,32-36)$. As is clear from the presented review, cancer as a long-term effect of the Holocaust represents a one-of-a-kind disease where oncology meets with history, politics, religion, human evil, suffering and dignity. After PTSD and other psychiatric disturbances, cardiovascular and other internal diseases, Holocaust-related cancer has to be intended as the last - in temporal succession - of the atrocities inflicted and bequeathed by the Nazi to the Jewry. A statistically significant association between cancer and HS was demonstrated in 10 studies $(16,23-31)$, whereas only 2 works did not find any difference with control groups $(32,34)$ and in 4 further studies of psychiatric interest the data was not even taken into account $(15,33,35,36)$. It is important to say that the papers finding a Holocaust-cancer correlation have been published more recently and by oncologically-oriented journals in comparison with the other publications (which did not find or investigate this feature) which appear more dated and focused on mental science. Several speculations have been advanced on etiopathogenesis of late-onset cancer occurring in HS $(26,27)$. During the Third Reich, all the HS constantly experienced extreme situations such as metabolic insults (famine with caloric restriction down to $220-800 \mathrm{kCal} /$ day with macro and micronutrient deficiency), environmental factors (cold winter temperatures, overcrowding, daily exposure to genotoxic waste produced by incinerators of the camps), biologic agents (infectious diseases, human experiments in death camps), physical (unceasing activity) and psycho-emotional (forced separation from family, seeing of relatives' and strangers' assassinations, coercion, exile, persecution, living under a false identity, anxiety, sleep deprivation,) abuse (26). Although starvation can theoretically reduce the procancer effects of some metabolic factors (reduction of body mass index and levels of sexual hormones with consecutive amenorrhea, late onset of menarche and early menopause), most studies showed that exposure to energy restriction (especially at an early age) was associated with an increased incidence of cancer compared to control groups (16, 23-26, 28-31): the epigenetic modifications (such as DNA hypermethylation causing chromosomal instability and oncogene activation) are thought by many the most plausible molecular pattern for explaining such a higher metabolicrelated cumulative risk of tumor $(26,28,30)$. As posited by the reviewed studies, stress is another condition impacting the risk of cancer through direct and indirect processes (26). The former include hormonal and immunologic pathways, the latter epigenetic modifications but also dangerous and alarming behaviors adopted in the postwar years such as smoking, alcohol abuse, obesity, insomnia, lack of sanitation and mistrust in medical profession and progress $(26,28,30)$. Interestingly, however, the risk of cancer for bereaved HS parents of an adult son do not seem to be modified in comparison with the control subjects suggesting that the (powerful) phenomenon of resilience could had been achieved by the HS group $(16,32)$. Finally, the poor and unhygienic conditions in the camps and ghettos increased exposure to infective agents such as hepatitis $\mathrm{B}$ and $\mathrm{C}$ virus, human papillomavirus and Helicobacter pylori with subsequent higher risk of developing liver, cervical and stomach cancer, respectively (26).

Limitations. Since all the reviewed studies were basically retrospective (even if some were "prospectivized" with questionnaires or other innovation), some data regarding the examined patient population are debatable (incomplete, ambiguous or simplified) and can reduce the conclusive quality of our review. For example, it is difficult to define with certainty the overall number of Israeli HS who developed late-onset cancer because of two main reasons. On the one hand, many articles drew data from the same National Registries in different periods of time, so the final results could be affected by numerical overlapping. On the other hand, the number can be affected by a misclassification with heterogeneous recruitment of the victims which, in turn, can derive from two not negligible aspects: the former is the different date and time limit of immigration to Israel entertained by the studies in order to acknowledge the status of HS, the latter concerns the definition of HS itself. In fact, since no individual information or validation regarding actual exposure to Holocaust was available through the studies and considering also that the official definition of HS makes no distinction by race, social background or nationality and covers a long span of time (from 1933 to 1945) (17), some authors differentiated the condition of HS on the different kinds of traumatic situations (death or concentration camps, ghettoes, hiding, persecution, partisan), others on the basis of a more generic direct or indirect exposure to Nazi regime, some others even in relation with a compensation classification according to Israeli laws (16, 26). Nevertheless, the final count of cancer Jewish Israeli HS cannot be inferior to 56060 subjects, which corresponds to the largest cHS population studied by Keinan-Boker and colleagues in 2009 (16). In five studies the cancer site was not declared $(23,24,31,32,34)$. Apart from oncologic 


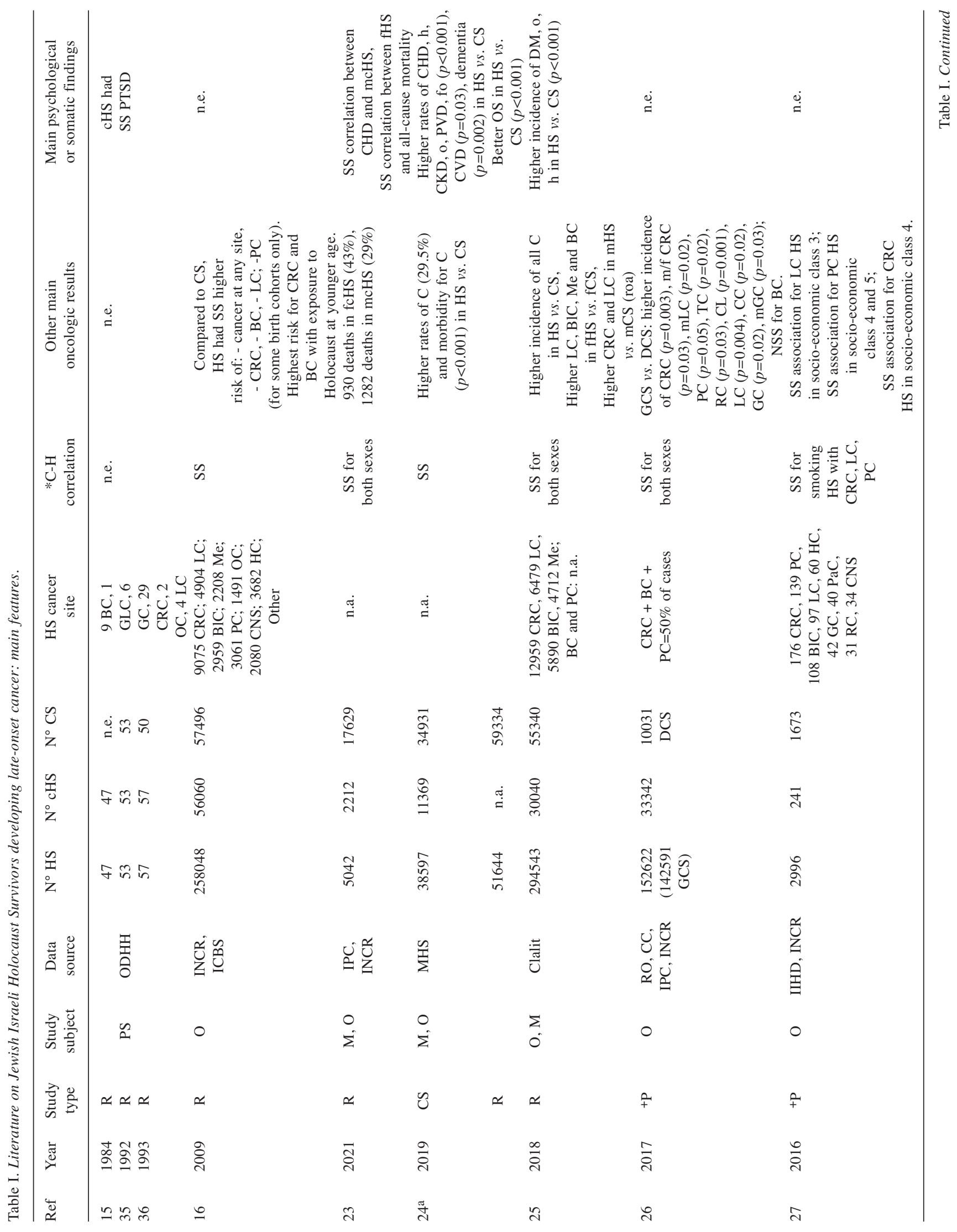




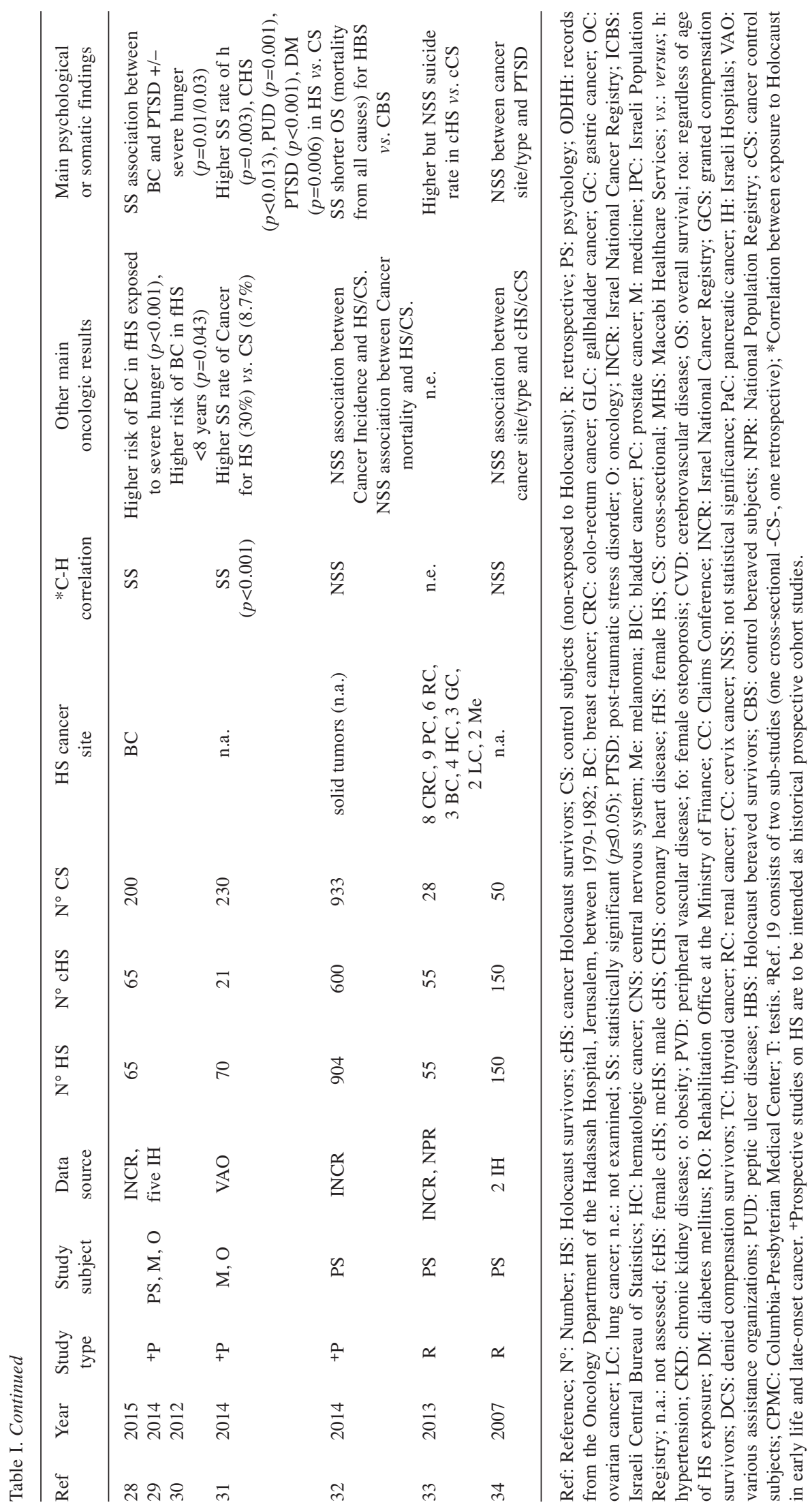


Table II. Main clinicopathologic features of Jewish Holocaust Survivors not resident or having resided in Israel (sources of public domain).

\begin{tabular}{|c|c|c|c|c|c|c|c|c|c|}
\hline \multirow{2}{*}{$\begin{array}{l}\text { Final Country } \\
\text { (native or } \\
\text { adoptive) }\end{array}$} & \multirow{2}{*}{$\begin{array}{c}\text { HS } \\
\text { number }\end{array}$} & \multirow{2}{*}{$\begin{array}{c}\text { Alive-Dead } \\
\text { HS* }\end{array}$} & \multirow{2}{*}{$\begin{array}{c}\text { HS with Notable Awards, } \\
\text { Accomplishments or Accolades }\end{array}$} & \multirow{2}{*}{$\begin{array}{c}\text { Death } \\
\text { Camp } \\
\text { Exposure }\end{array}$} & \multicolumn{5}{|c|}{ Cause of death: } \\
\hline & & & & & Cancer & $\mathrm{CV}$ & Suicide & $\begin{array}{c}\text { Lung/ } \\
\text { Covid-19 }\end{array}$ & Other \\
\hline USA & 83 & $\begin{array}{l}\text { Alive: } \\
9 \text { Dead: } 74\end{array}$ & $\begin{array}{c}\text { Gertrude Kleinová: Ping Pong World } \\
\text { Championship (1935-6); } \\
\text { Emilio Segrè: Nobel Prize in Physics (1959); } \\
\text { Salvatore Luria: Nobel Prize in } \\
\text { Physiology or Medicine (1969); } \\
\text { Roald Hoffmann: Nobel Prize } \\
\text { in Chemistry (1981); } \\
\text { Franco Modigliani: Nobel Prize } \\
\text { in Economics (1985); Elie Wiesel: } \\
\text { Nobel Peace Prize in (1986); } \\
\text { Bruno Rossi: Wolf Prize in } \\
\text { Physics (1987); Billy Wilder: } \\
\text { 7 Academy Awards (1946-1988); } \\
\text { Walter Kohn: Nobel Prize in Chemistry (1998); } \\
\text { Daniel Kahneman: Nobel Prize } \\
\text { in Economics (2002); } \\
\text { Mario Capecchi: Nobel Prize in } \\
\text { Physiology/Medicine (2007); } \\
\text { Tom Lantos: Member of USA Representative } \\
\text { from California (1981-2008). }\end{array}$ & 61 & 22 & 13 & 2 & 1 & 36 \\
\hline Italy & 60 & $\begin{array}{c}\text { Alive: } \\
\text { 12 Dead: } 48\end{array}$ & $\begin{array}{l}\text { Carlo Levi: author of the best-selling } 1945 \\
\text { memoir Christ stopped at Eboli; } \\
\text { Primo Levi: author of the bestselling } 1947 \\
\text { memoir Se questo è un uomo (Survival in } \\
\text { Aushwitz) (2600000 copies sold only in Italy); } \\
\text { Giorgio Bassani: writer of } 1962 \text { The Garden } \\
\text { of the Finzi-Continis (adaption by Vittorio } \\
\text { De Sica won } 1972 \text { Academy Award for } \\
\text { Best Foreign Language Film and 21 } 1 \text { st Berlin } \\
\text { Golden Bear); Giuseppe Levi (1872-65): } \\
\text { scientific tutor of } 3 \text { future Italian Nobel Prizes } \\
\text { (Rita Levi-Montalcini, Dulbecco, Luria) } \\
\text { and father of writer Natalia Ginzburg; } \\
\text { Rita Levi-Montalcini: Nobel Prize in } \\
\text { Physiology/Medicine (1986); Liliana Segre: } \\
\text { Italian Senator for life since 2018. }\end{array}$ & 39 & 5 & 8 & 2 & 0 & 33 \\
\hline France & 20 & $\begin{array}{l}\text { Alive: } 4 \\
\text { Dead: } 16\end{array}$ & $\begin{array}{c}\text { Pierre Seel: spokesman of Gay Holocaust; } \\
\text { Marc Chagall: major artist; } \\
\text { Marcel Marceau: legend of pantomime } \\
\text { inventing the moonwalk dance; } \\
\text { Roman Polanski: film director whose } \\
\text { productions received } 8 \text { Academy Awards } \\
\text { from } 1962 \text { to date; Georges Charpak: } \\
\text { Nobel Prize in Physics (1992); Alfred Nachake: } \\
\text { swimming champion member of the } \\
\text { International Jewish Sports } \\
\text { Hall of Fame since 1993. }\end{array}$ & 11 & 3 & 1 & 1 & 0 & 11 \\
\hline UK & 17 & $\begin{array}{l}\text { Alive: } 5 \\
\text { Dead: } 12\end{array}$ & $\begin{array}{l}\text { Arnaldo Momigliano: historian characterized } \\
\text { by Donald Kagan as the world's leading } \\
\text { student of the writing of history in the } \\
\text { ancient world; Ingrid Pitt: actress } \\
\text { in Doctor Zhivago and horror films; } \\
\text { Karel Reisz: filmmaker pioneer of the new } \\
\text { realist strain; Ben Helfgott: champion } \\
\text { weightlifter between 1950-1958. }\end{array}$ & 12 & 3 & 1 & 0 & 1 & 7 \\
\hline
\end{tabular}


Table II. Continued

\begin{tabular}{|c|c|c|c|c|c|c|c|c|c|}
\hline \multirow{2}{*}{$\begin{array}{l}\text { Final Country } \\
\text { (native or } \\
\text { adoptive) }\end{array}$} & \multirow{2}{*}{$\begin{array}{c}\text { HS } \\
\text { number }\end{array}$} & \multirow{2}{*}{$\begin{array}{c}\text { Alive-Dead } \\
\text { HS* }\end{array}$} & \multirow{2}{*}{$\begin{array}{l}\text { HS with Notable Awards, } \\
\text { Accomplishments or Accolades }\end{array}$} & \multirow{2}{*}{$\begin{array}{l}\text { Death } \\
\text { Camp } \\
\text { Exposure }\end{array}$} & \multicolumn{5}{|c|}{ Cause of death: } \\
\hline & & & & & Cancer & $\mathrm{CV}$ & Suicide & $\begin{array}{l}\text { Lung/ } \\
\text { Covid-19 }\end{array}$ & Other \\
\hline Canada & 7 & $\begin{array}{l}\text { Alive: } 0 \\
\text { Dead: } 7\end{array}$ & $\begin{array}{l}\text { Rudolf Vrba: known for the Vrba-Wetzler } \\
\text { report (1944), the document which prompted } \\
\text { an end to the deportation of Hungarian Jews } \\
\text { to Auschwitz saving around } 200000 \text { lives. }\end{array}$ & 5 & 2 & 4 & 0 & 0 & 1 \\
\hline Switzerland & 7 & $\begin{array}{l}\text { Alive: } 0 \\
\text { Dead: } 7\end{array}$ & $\begin{array}{l}\text { Otto Frank: The Diary of Anne Frank has sold } \\
35 \text { million copies worldwide from } 1947 \text { to date; } \\
\text { Elias Canetti: Nobel Prize in Literature (1981); } \\
\text { Jack Steinberger: Nobel Prize in Physics (1988) } \\
\text { (Covid-death); Ota Sik: proponent of the } \\
\text { Czech New Economic Model. }\end{array}$ & 3 & 2 & 1 & 0 & 1 & 3 \\
\hline Others & 136 & $\begin{array}{l}\text { Alive: } 18 \\
\text { Dead: } 118\end{array}$ & $\begin{array}{l}\text { Imre Kertész: Hungarian novelist winning } \\
\text { Nobel Prize in Literature (2002); } \\
\text { Branko Lustig: Croatian film producer } \\
\text { winning Academy Awards for Best Picture } \\
\text { for Schindler's List; François Englert: } \\
\text { Belgium, Nobel Prize in Physics (2013); } \\
\text { Simon Wiesenthal: Nazi hunter. }\end{array}$ & 89 & 13 & 10 & 5 & 3 & 87 \\
\hline
\end{tabular}

*Number of alive or dead Holocaust survivors as of March 2021. HS: Holocaust survivors; CV: cardiovascular disease; Covid-19: Coronavirus diseases 2019.

papers, classification for tumor staging has not been reported; histologic characterization of cancers (such as adenocarcinoma versus squamous cell carcinoma for lung malignancy, ductal versus lobular for breast cancer) is never made explicit through the manuscripts $(15,16,23-36)$. In the end, the works that have been published on psychiatric journals often fail to express important oncologic and prognostic features $(15,32-36)$.

Colorectal cancer. Colorectal cancer (CRC) in HS has been explicitly addressed in 8 studies $(15,16,25-27,33,35,36)$. In four of these (which constitute the $99 \%$ of the declared CRC HS population - that is 27,210 of 27,415 subjects), the Holocaust has been regarded a significant risk factor of CRC $(16,25-27)$. Having suffered the prolonged, severe and imbalanced caloric restriction lacking in fruit, vegetables, fiber, calcium, folic acid and vitamin D could undoubtedly take part to this type of enteral carcinogenesis (26). Moreover, differently from non-Jewish population, Ashkenazi Jews (who constitute around $75 \%$ of world Jewry today, $92 \%$ before WWII) could be affected with a hereditary form of CRC characterized by mutations of tumor suppressor genes coding for Breast Related Cancer Antigens 1 or 2 (BRCA1 and BRCA2): such a genetic predisposition could differ from the mechanisms commonly involved in the inherited or sporadic forms of CRC affecting the rest of the general population and also take part in the higher CRC rates observed in HS through the reviewed studies (37-41).
Breast cancer. Breast cancer (BC) occurring in HS was specifically studied and analyzed by the research group headed by Vin-Raviv and Keinan-Boker for which they published at least three dedicated articles (28-30). According to their results, compared to the control groups, HS represented a population more susceptible for late-onset $\mathrm{BC}$ because of caloric restriction experienced during the War years: more precisely, women who were severely exposed to the hunger $(p<0.001)$ at a younger age $(0-7$ years, $p=0.043)$ had a statistically significant higher risk of BC (30). Among the causes, the authors also suggested poorer health behaviors (such as higher levels of smoking and alcohol consumption) adopted by PTSD women as stress relief techniques (29). Furthermore, it has been documented since several decades that Jewish women suffer from a genetic predisposition for BC. Ashkenazi Jewish patients, in fact, often develop a genetic (mutations in BRCA 1 and BRCA 2) or familial form of BC or ovarian cancer (42). Moreover, their response to chemoradiation can be less effective than the one registered in the rest of population (43).

Lung cancer. At least 11,486 HS with late-onset lung cancer (LC) have been enumerated through the reviewed studies (16, $25-27,33)$. The association between LC and Holocaust has been resulted statistically significant in all of these $(p<0.05$ for references 16, 25, 27; $p=0.008$ for reference 26). As initially hypothesized and, once that the information on the smoking status of the study participants was available, later 
observed by Keinan-Boker and colleagues, tobacco smoking, which is the best-known risk factor for lung and bronchial adenocarcinoma, was more prevalent in the exposed than in the non-exposed group $(16,27)$. Moreover, as smoking is more frequent in people with PTSD, the higher risk of LC could also be related to PTSD itself (16). Finally, the higher risk of LC in HS could also derive from chronic respiratory conditions (such as chronic obstructive lung disease, emphysema, bronchiectasis and tuberculosis) which were acutely suffered during the years lived in the camps and that, sustained by chronic protumor inflammation, could progressively have turned into malignant transformation (16).

Prostate cancer. Correlation of prostate cancer (PC) with Holocaust has been clearly evaluated in 4 studies for an approximate total of 8,209 declared cases $(16,25-27)$. In all, the risk of developing PC resulted higher in survivors who lived in countries under the Third Reich compared with countries not governed by Nazi Germany $(p \leq 0.05)$ (26). Caloric restriction can potentially explain such an increased risk of PC: besides lack of vitamin D, E, selenium and calcium, murine models submitted to starvation showed higher plasma levels of insulin-like growth factor I which has already been positively associated with PC risk $(16,27)$.

Melanoma. Melanoma has been addressed in three studies entertaining a total of $6,922 \mathrm{HS}(16,25,33)$. David and colleagues found that HS had statistically significant higher rates of incidence and relative risk of melanoma than the comparison group (25). An age-stratified analysis, moreover, disclosed a higher risk for women experiencing the Holocaust as adults ( $>18$ years of age) whereas for men as children ( $<18$ years) (25). The authors correlated such results to the prolonged exposure, from sunrise to sunset, to ultraviolet radiation, the absence of sunscreen protections and the light skin of the Eastern European Jews (25).

Review and retrospective analysis of the public domain information available on noted Jewish non-Israeli Survivors developing late-onset cancer. By reviewing the literature on Jewish non-Israeli cHS, we found only one paper (single case report) dealing with an American 78year-old man affected with a giant malignant fibrous histiocytoma of the testis/spermatic cord measuring $27 \times 22 \times 17 \mathrm{~cm}$ and weighing $6.3 \mathrm{~kg}(44)$. Forty-eight years before, in 1943, he was a human experimental subject interned at the Auschwitz concentration camp where an assistant of Dr. Joseph Mengele injected an unknown substance into his left testicle followed by transient local pain and swelling (44). Due to missing pertinent literature, we proceeded with reviewing the public domain information available on the internet surrounding some noted Jewish HS not resident or having resided in Israel.
Table III. Univariate analysis of Holocaust as risk factor for diseases in Jewish survivors not resident or having resided in Israel.

\begin{tabular}{lc}
\hline Variable & $p$-Value \\
\hline Cancer & $\mathbf{< 0 . 0 0 0 1}$ \\
Cardiovascular disease & $\mathbf{< 0 . 0 0 0 1}$ \\
PTSD & $\mathbf{< 0 . 0 0 0 1}$ \\
Lung disease/COVID-19 & $\mathbf{< 0 . 0 0 0 1}$ \\
\hline
\end{tabular}

PTSD: Post-Traumatic Stress Disorder; COVID-19: coronavirus disease 2019; statistically significant $p$-Values are shown in bold.

Table IV. Associations between overall mortality and Holocaust-related late-onset diseases in Jewish non-Israeli survivors.

\begin{tabular}{lc}
\hline Holocaust-related disease & $p$-Value \\
\hline Cancer & $\mathbf{0 . 0 0 0 1}$ \\
Cardiovascular disease & $\mathbf{0 . 0 0 7 2}$ \\
PTSD and PTSD-related suicide & 0.140 \\
Lung disease/COVID-19 & 0.230 \\
Exposure to death/concentration camp & 0.153 \\
\hline
\end{tabular}

PTSD: Post-traumatic stress disorder; COVID-19: coronavirus disease 2019; statistically significant $p$-Values are shown in bold.

We made a retrospective analysis of the collected data including the aforementioned case report (Table II). We selected 330 noted HS: as of March 2021, there are 48 (14.5\%) noted Jews still alive. In the case of malignancy, information on the type and site of cancer was not always accessible: of the 50 cancer cases found, 5 were lung, 3 gastric, 3 prostate, 2 pancreatic, 2 breast, 2 lymphomatous, 1 ovarian, 1 maxillary, 1 urothelial (bladder), 1 esophageal and 1 malignant melanoma whereas the information was not declared for the remainder (Table II). Besides cancer, other pathological causes of death were cardiovascular disease (38 cases), PTSD-related suicide (10 cases) and 6 cases of pneumonia (including 2 deaths for coronavirus disease 2019 - COVID-19); the other 178 subjects died of aging or other illnesses not otherwise specified. As for exposure to extermination/concentration camps, $220 \mathrm{HS}$ were interned $(66.6 \%)$. At univariate analysis, Holocaust was a significant risk factor for cancer, cardiovascular disease, PTSD and pulmonary (including COVID-19) disease $(p<0.0001$ for each associated variable) (Table III). Exposure to extermination/concentration camp, on the contrary, was not statistically correlated with cancer $(p=0.166)$. Overall mortality was significantly impacted by Holocaust-related cancer $(p=0.0001$ with an OR $>32$ and $p=0.0148)$ and cardiovascular disease $(p=0.0072$ with an OR $>5$ and $p=0.0166$ ) whereas no significant difference 


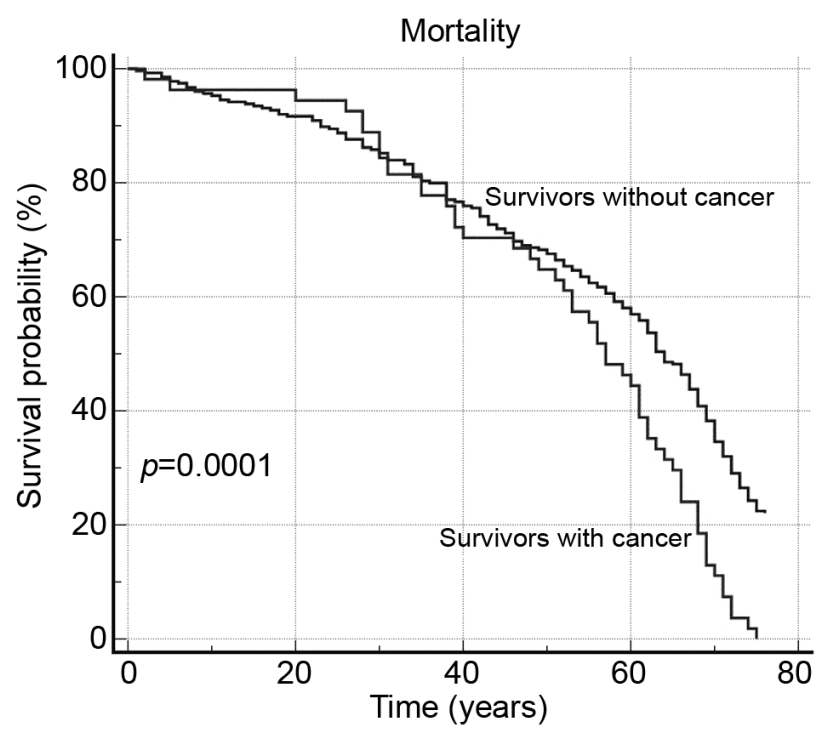

Figure 1. Kaplan-Meier curves showing statistical differences in survival among Jewish non-Israeli Holocaust survivors with and without cancer.

was observed after PTSD-related suicide, pulmonary disease/COVID-19 or exposure to death/concentration camp $(p=0.140,0.230$ and 0.153 , respectively) (Table IV). At multivariate analysis, cardiovascular disease was the only independent risk factor for mortality in HS $(p=0.003)$ (Table V). HS with cancer (57 vs. 64 years, $p=0.0001$, Figure 1), cardiovascular disease (48vs. 64 years, $p<0.0001$, Figure 2) and PTSD (34 vs. 63 years, $p<0.0001$, Figure 3) had a significantly shorter survival compared to their healthy control counterparts whereas no difference was seen in pulmonary disease and camp-exposed groups. At multivariate survival analysis, Holocaust-related cancer, cardiovascular disease and PTSD resulted to be independent risk factors of poor prognosis $(p<0.0001$ for each variable, Table VI). In the light of our analysis, we can infer that the Holocaust was significantly associated with late-onset development of diseases like cancer, cardiovascular disorder, PTSD and pulmonary illness (including COVID-19), in the examined population made of noted Jewish survivors not resident or having resided in Israel. Moreover, for the same population, Holocaust-related late-onset cancer, cardiovascular disease and PTSD resulted in being independent risk factors for worse prognosis and mortality. The lack of statistical relationship of camp exposure with cancer could result from the small size of the sample and/or from the resilience achieved by such victims over-exposed to Nazi atrocities $(16,32)$. Although our results are in accordance with those concerning the Jewish Israeli survivors $(15,16,23-36,45)$, further studies enrolling more non-noted Jewish non-Israeli HS are needed for corroboration.

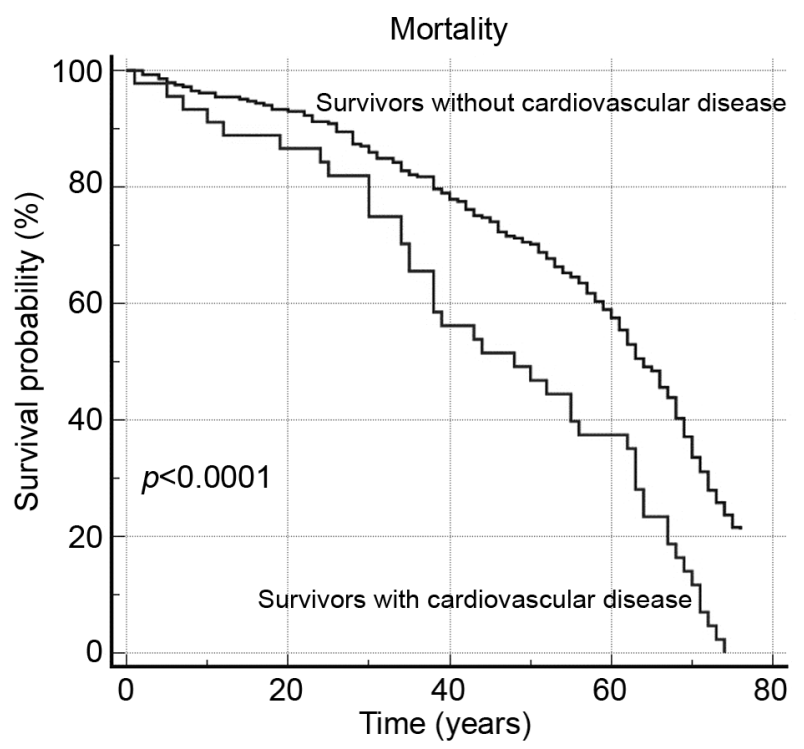

Figure 2. The Kaplan-Meier method showed significantly different survival curves among Jewish non-Israeli Holocaust survivors with and without cardiovascular disease.

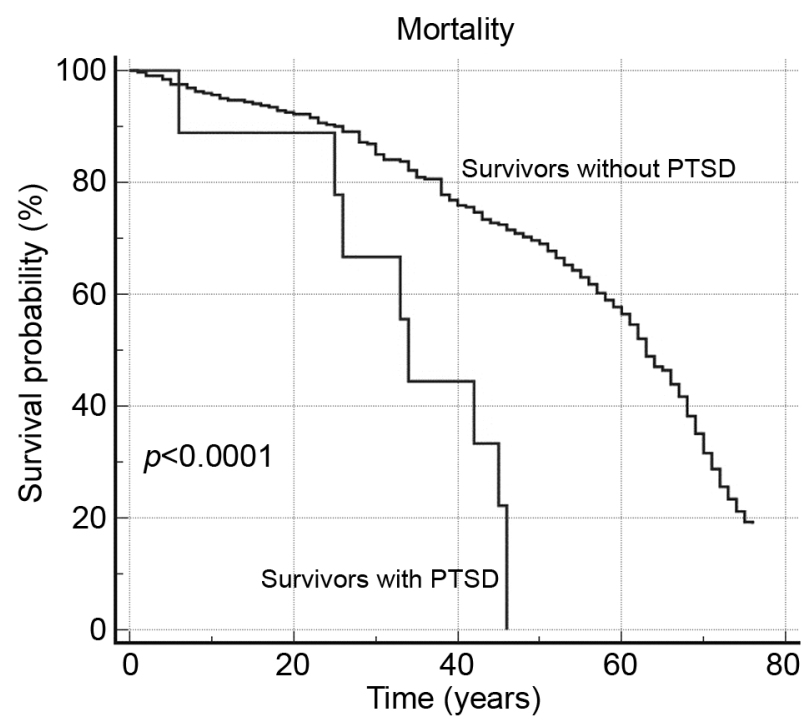

Figure 3. At Kaplan-Meier survival analysis, Jewish non-Israeli Holocaust survivors with Post-Traumatic Stress Disorder (PTSD) showed poorer prognosis compared to survivors without it.

Literature on non-Jewish Holocaust Survivors developing late-onset cancer. Several studies investigated cancer incidence occurring in many countries under the German occupation (1940-1945) and analyzed the correlation with stress, starvation and other conditions experienced by the local populations (46-60). 
Table V. Multivariate analysis (logistic regression) of independent risk factors for mortality in Jewish Holocaust survivors not living or having lived in Israel.

\begin{tabular}{lcccc}
\hline Variable & Coefficient & Standard error & Wald & $p$-Value \\
\hline Cardiovascular disease & 2.19913 & 0.74207 & 8.7824 & $\mathbf{0 . 0 0 3}$ \\
Exposure to death/concentration camp & 0.49356 & 0.30957 & 2.5419 & 0.110 \\
Cancer & 22.20553 & $8,977.90821$ & 0.000006117 & 0.998 \\
PTSD & 22.34194 & $22,024.21923$ & 0.000001029 & 0.999 \\
Lung disease/COVID-19 & 22.10160 & $26,497.14850$ & 0.0000006957 & 0.999 \\
Constant & 0.61120 & 0.25021 & 5.9668 & $\mathbf{0 . 0 1 4 6}$ \\
\hline
\end{tabular}

Overall Model Significance Level: $\boldsymbol{p}<\mathbf{0 . 0 0 1}$

PTSD: Post-traumatic Stress Disorder; COVID-19: coronavirus disease 2019; the Wald statistic is the regression coefficient (b) divided by its standard error squared; statistically significant $p$-Values are shown in bold.

Table VI. Multivariate survival analysis (Cox proportional hazards model) of independent covariates (Holocaust-related diseases) impacting the prognosis of Jewish survivors not resident or having resided in Israel.

\begin{tabular}{lcccccc}
\hline Covariate & $\mathrm{b}$ & $\mathrm{SE}$ & Wald & $p$-Value & Exp(b) & $95 \%$ CI of Exp(b) \\
\hline Cancer & 0.8189 & 0.1615 & 25.7070 & $\mathbf{< 0 . 0 0 0 1}$ & 2.2679 & $1.6525-3.1125$ \\
Cardiovascular disease & 0.9799 & 0.1759 & 31.0388 & $\mathbf{< 0 . 0 0 0 1}$ & 2.6643 & $1.8874-3.7611$ \\
PTSD & 1.9302 & 0.3580 & 29.0753 & $\mathbf{< 0 . 0 0 0 1}$ & 6.8909 & $3.4164-13.8990$ \\
Lung disease/COVID-19 & 0.3259 & 0.4147 & 0.6179 & 0.4318 & 1.3853 & $0.6146-3.1226$ \\
Exposure to death/concentration camp & 0.003421 & 0.1340 & 0.0006521 & 0.9796 & 1.0034 & $0.7717-1.3048$ \\
\hline
\end{tabular}

Overall Model Significance Level: $\boldsymbol{p}<\mathbf{0 . 0 0 0 1}$

PTSD: Post-traumatic stress disorder; COVID-19: coronavirus disease 2019; b: regression coefficient; SE: standard error; The Wald statistic is the regression coefficient (b) divided by its standard error squared: (b/SE) ${ }^{2}$; $\operatorname{Exp}(\mathrm{b})$ : exponentiation of the B coefficient, which is an odds ratio; CI: confidence interval; statistically significant $p$-Values are shown in bold.

In Norway, as for CRC, one study described a drop in incidence among the cohorts born during or shortly after WWII and related such a finding to the caloric restriction experienced by the population during those difficult years (46); a similar tendency of decreased risk was observed in other Nordic countries such as Estonia, Sweden and Denmark (47). On the other hand, always in Norway, hyponutrition was strongly associated with women born (48) or being adolescent $(49,50)$ during WWII.

In the Netherlands, seven studies investigated the long-term effects of the "Hunger Winter" which was imposed by the Third Reich from September 1944 to May 1945. In four of these no association of the "Dutch Famine" with CRC (51, $52), \mathrm{BC}(53)$ and prostate cancer (54) was found. The other three, conversely, demonstrated a statistical correlation (5557). Simons and colleagues reported a significantly higher risk of developing CRC characterized by epigenetic alterations (methylation of insulin-like growth factor-binding protein genes) among survivors exposed to early-life energy restriction (55) while Elias et al. found a $13 \%$ increased risk of BC $(p=0.016)$ in women who were moderately exposed to the famine $(56,57)$.
BC was significantly associated with the undernourishmentrelated delay in menarche among the women who remained as adolescents in Guernsey (a British island sited in the English Channel between Normandy and United Kingdom) during the German Occupation (58).

In Russia, similarly, women aged 10-18 years suffering from the siege of Leningrad had a higher risk of dying from $\mathrm{BC}$ compared with unexposed women born during the same period; male PC did not achieve the same result (59).

Several members of the Resistance movements of the European countries developed malignancies in the aftermath of WWII $(60,61)$. John Lyng, Prime Minister of Norway in 1963, was a member of Norwegian Resistance during the occupation of Norway by Nazi Germany: he died of lung cancer in 1978 (60). Beppe Fenoglio, Italian author of the novel "Johnny the Partisan", took part in the National Resistance: he lately died of bronchial cancer aged 40 (61).

\section{Conclusion}

In the light of our review, 76 years after its official ending, the Holocaust keeps on burdening the life of its survivors. To the 
horrors, atrocities and early sequelae experienced by the surviving victims during and in the early aftermath of the Nazi era, in fact, should be added the delayed effects of the Holocaust, such as cardiovascular disease, PTSD and pulmonary disorders. The late-onset development of cancers represents a further terrible manifestation of the enduring affliction inflicted by the Nazis to their victims. As argued also in this review, such malignancies can derive from direct or indirect causes (even a combination of both) and affect virtually every organ of human body, but mainly those belonging to digestive, respiratory, integumentary and male/female reproductive system. The delayed Holocaust-related diseases (including cancer) undoubtedly diverge from early-onset forms for being spaced by several decades and occurring in different historical moments (from the Third Reich to the European Union through the establishment of the State of Israel). In our opinion, there is also a further important distinction to highlight: the medical ethics with the role played by the Nazi doctors. Early-onset diseases, in fact, were caused with the complicity, active collaboration and dehumanization of the medical profession (1-6). Prompted by venomous and envious feelings for Jews, career ambition, illusory superiority, delusions of grandeur and economic grounds (before the rise of National Socialism there was a $41 \%$ drop in incomes for physicians in Germany), the German medical establishment conducted a rapid immoral transition from healer to murderer which started with the collusion in the exclusion of Jewish physicians from the medical profession betraying the same oaths and codes sworn years before as university students with their Jewish classmates (3). "Of course I am a doctor and I want to preserve life. My Hippocratic oath tells me to cut a gangrenous appendix out of a diseased body. The Jews are the gangrenous appendix in the body of mankind. That's why I cut them out." declared the Nazi doctor Fritz Klein in 1945 during the Belsen trial (4). In the setting of late-onset Holocaustrelated diseases, conversely, by treating the HS, the physicians of today have the chance to redeem and rehab our entire working class and, mostly, make up for those indelible stains. Paralleling clinicians, our young researchers should always keep in mind that the foundations for the principles regarding human subjects research, experimentation and institutional review boards (embodied in the 1964 Declaration of Helsinki and its latest revisions) were laid down during the Nuremberg trials resulting in the so-called Nuremberg Code: to commit their horrendous abuses (sterilization, euthanasia of disabled patients, murders, experiments, etc.), in fact, Nazi scientists and physicians have never asked for a free and voluntary informed consent from Holocaust victims $(2,62)$. By adopting the ethical principles in our researches, hence, every day we unwittingly remember and honor the victims and survivors of Holocaust and become vigilant about preventing potential immoral recurrences: "I have learnt a lot of things studying the Holocaust. But to me, the most important thing was the possible dehumanization of Medicine. It happened once, so it could happen again." commented Beatriz, a $2^{\text {nd }}$ year medical student, after a study trip to the Holocaust and Medicine-related sites in Poland (63).

\section{Conflicts of Interest}

The Authors declare no conflicts of interest.

\section{Authors' Contributions}

All the Authors agreed with the content of the article. Dr. Virgilio conceived the presented research and wrote the manuscript. Dr. Virgilio, Dr. Camilli and Dr. Gili examined the historical aspects. Dr. Virgilio, Dr. Annicchiarico, Dr. Pagliai and Dr. Romboli reviewed the literature. Dr. Virgilio, Dr. Morini and Dr. Costi reviewed the public domain information on Holocaust survivors. Dr. Virgilio, Dr. Montali and Dr. Salvemini performed the statistical analysis. Dr. Virgilio and Prof. Costi supervised the entire project.

\section{References}

1 Chelouche T: Teaching hard truths about medicine and the Holocaust. AMA J Ethics 23(1): E59-E63, 2021. PMID: 33554850. DOI: 10.1001/amajethics.2021.59

2 Reis SP and Wald HS: Learning from the past: medicine and the Holocaust. Lancet 374(9684): 110-111, 2009. PMID: 19606544. DOI: $10.1016 / \mathrm{s} 0140-6736(09) 61275-7$

3 Geiderman JM: Ethics seminars: physician complicity in the Holocaust: historical review and reflections on emergency medicine in the 21st century, part I. Acad Emerg Med 9(3): 223-231, 2002. PMID: 11874788. DOI: 10.1111/j.1553-2712.2002.tb00254.x

4 Colaianni A: A long shadow: Nazi doctors, moral vulnerability and contemporary medical culture. J Med Ethics 38(7): 435-438, 2012. PMID: 22556311. DOI: 10.1136/medethics-2011-100372

5 Alexander L: Medical science under dictatorship. N Engl J Med 241(2): 39-47, 1949. PMID: 18153643. DOI: 10.1056/ NEJM194907142410201

6 Mitscherlich A, Mielke F and Norden H: Doctors of infamy: the story of the Nazi medical crimes. JAMA 141(16): 1195, 1949. DOI: $10.1001 /$ jama.1949.02910160085034

7 The Economist: A memorial and a name. Jan 25th 2020 edition. Available at: https://www.economist.com/graphic-detail/2020/ 01/25/archivists-are-racing-to-identify-every-jewish-holocaustvictim [Last accessed on May 7, 2021]

8 The New York Times: Survivors get a vaccine on Holocaust Remembrance Day. Jan 27th 2021. Available at: https://www.nytimes.com/2021/01/27/world/holocaustremembrance-vaccines.html [Last accessed on May 7, 2021]

9 Paratz ED and Katz B: Ageing Holocaust survivors in Australia. Med J Aust 194(4): 194-197, 2011. PMID: 21401461. DOI: 10.5694/j.1326-5377.2011.tb03771.x

10 Shuval J: Some persistent effects of trauma: five years after the Nazi concentration camps. Social Problems 5(3): 230-243, 2019. DOI: $10.2307 / 798965$

11 Levav I and Klomek AB: A review of epidemiologic studies on suicide before, during, and after the Holocaust. Psychiatry Res 261: 35-39, 2018. PMID: 29276992. DOI: 10.1016/ j.psychres.2017.12.042 
12 Maytles R, Frenkel-Yosef M and Shrira A: Psychological reactions of Holocaust survivors with low and high PTSD symptom levels during the COVID-19 pandemic. J Affect Disord 282: 697-699, 2021. PMID: 33445095. DOI: 10.1016/ j.jad.2021.01.007

13 Castle DJ and Murray RM: The epidemiology of late-onset schizophrenia. Schizophr Bull 19(4): 691-700, 1993. PMID: 8303220. DOI: $10.1093 / \mathrm{schbul} / 19.4 .691$

14 Sperling W, Kreil S and Biermann T: Somatic diseases in child survivors of the Holocaust with posttraumatic stress disorder: a comparative study. J Nerv Ment Dis 200(5): 423-428, 2012. PMID: 22551796. DOI: 10.1097/NMD.0b013e318253229e

15 Baider L and Sarell M: Coping with cancer among holocaust survivors in Israel: an exploratory study. J Human Stress 10(3): 121 127, 1984. PMID: 6520392. DOI: 10.1080/0097840X.1984.9934965

16 Keinan-Boker L, Vin-Raviv N, Liphshitz I, Linn S and Barchana M: Cancer incidence in Israeli Jewish survivors of World War II. J Natl Cancer Inst 101(21): 1489-1500, 2009. PMID: 19861305. DOI: 10.1093/jnci/djp327

17 Brodsky J, Sharon A, King Y, Be'er S and Shnoor Y: Holocaust survivors in Israel: population estimates, demographic, health and social characteristics, and needs. Myers-JDC-Brookdale Institute, Jerusalem, Israel. 2010. (RR-553-10). Available at www.jdc.org.i1/brookdale [Last accessed on May 7, 2021]

18 Memorial Archives. Available at: https://memorialarchives.international/ [Last accessed on May 7, 2021]

19 United States Holocaust Memorial Museum. Available at: https://www.ushmm.org/ [Last accessed on May 7, 2021]

20 Fondazione Centro di Documentazione Ebraica Contemporanea. Available at: https://www.cdec.it/ [Last accessed on May 7, 2021]

21 Camilli D and De Vito R: Concentrare, Sterminare. Essere è ricordare. Intermedia snc (eds.). Orvieto, pp 1-227, 2014.

22 List of Holocaust survivors. Available at: https:// en.wikipedia.org/wiki/List_of_Holocaust_survivors [Last accessed on May 7, 2021]

23 Youssim I, Gorfine M, Calderon-Margalit R, Manor O, Paltiel O, Siscovick DS, Friedlander Y and Hochner H: Holocaust experience and mortality patterns: 4-decade follow-up in a population-based cohort. Am J Epidemiol, 2021. PMID: 33564866. DOI: 10.1093/aje/kwab021

24 Fund N, Ash N, Porath A, Shalev V and Koren G: Comparison of mortality and comorbidity rates between holocaust survivors and individuals in the general population in Israel. JAMA Netw Open 2(1): e186643, 2019. PMID: 30646191. DOI: 10.1001/ jamanetworkopen.2018.6643

25 Ben David R, Biderman A, Sherf M, Zamstein O and Dreiher J: Elevated cancer risk in Holocaust survivors residing in Israel: A retrospective cohort study. Eur J Cancer 95: 85-92, 2018. PMID: 29655060. DOI: 10.1016/j.ejca.2018.03.011

26 Sadetzki S, Chetrit A, Freedman LS, Hakak N, Barchana M, Catane R and Shani M: Cancer risk among Holocaust survivors in Israel-A nationwide study. Cancer 123(17): 3335-3345, 2017. PMID: 28691178. DOI: 10.1002/cncr.30783

27 Keinan-Boker L and Goldbourt U: Cancer incidence in Holocaust male survivors-An Israeli cohort study. Int J Cancer 139(11): 2426-2435, 2016. PMID: 27509441. DOI: 10.1002/ijc.30378

28 Vin-Raviv N, Barchana M, Linn S and Keinan-Boker L: Severe caloric restriction in young women during World War II and subsequent breast cancer risk. Int J Clin Pract 66(10): 948-958, 2012. PMID: 22994329. DOI: 10.1111/j.1742-1241.2012.02966.x
29 Vin-Raviv N, Dekel R, Barchana M, Linn S and Keinan-Boker L: World War II-related post-traumatic stress disorder and breast cancer risk among Israeli women: a case-control study. Int Psychogeriatr 26(3): 499-508, 2014. PMID: 24290080. DOI: $10.1017 / \mathrm{S} 1041610213002081$

30 Vin-Raviv N, Dekel R, Barchana M, Linn S and Keinan-Boker L: Challenges in recruiting aging women Holocaust survivors to a case control study of breast cancer. Res Gerontol Nurs $8(6)$ : 265-272, 2015. PMID: 26020580. DOI: 10.3928/1940492120150522-07

31 Bercovich E, Keinan-Boker L and Shasha SM: Long-term health effects in adults born during the Holocaust. Isr Med Assoc J 16(4): 203-207, 2014. PMID: 24834754.

32 Kohn R, Levav I, Liphshitz I, Barchana M and Keinan-Boker L: Cancer incidence and mortality following exposures to distal and proximal major stressors. Soc Psychiatry Psychiatr Epidemiol 49(5): 703-709, 2014. PMID: 24318123. DOI: 10.1007/s00127013-0805-9

33 Nakash O, Liphshitz I, Keinan-Boker L and Levav I: The effect of cancer on suicide among elderly Holocaust survivors. Suicide Life Threat Behav 43(3): 290-295, 2013. PMID: 23379368. DOI: $10.1111 /$ sltb.12015

34 Hantman S and Solomon Z: Recurrent trauma: Holocaust survivors cope with aging and cancer. Soc Psychiatry Psychiatr Epidemiol 42(5): 396-402, 2007. PMID: 17384892. DOI: $10.1007 / \mathrm{s} 00127-007-0177-0$

35 Baider L, Peretz T and Kaplan De-Nour A: Effect of the Holocaust on coping with cancer. Soc Sci Med 34(1): 11-15, 1992. PMID: 1738851. DOI: 10.1016/0277-9536(92)90061-t

36 Baider L, Peretz T and De-Nour AK: Holocaust cancer patients: a comparative study. Psychiatry 56(4): 349-355, 1993. PMID: 8295973. DOI: 10.1080/00332747.1993.11024657

37 Drucker L, Stackievitz R, Shpitz B and Yarkoni S: Incidence of BRCA1 and BRCA2 mutations in Ashkenazi colorectal cancer patients: preliminary study. Anticancer Res 20(1B): 559-561, 2000. PMID: 10769725.

38 Virgilio E, Balducci G, Mercantini P, Ferri M, Palumbo A, Pilozzi $\mathrm{E}$ and Cavallini M: Curative and prophylactic surgery of youngonset colorectal cancer in inherited syndromes: a 15-year monocentric retrospective experience. Anticancer Res 39(6): 31313136, 2019. PMID: 31177158. DOI: 10.21873/anticanres.13449

39 Annicchiarico A, Morini A, Romboli A, RiccÒ M, Leonardi F, Crafa P, Virgilio E, Dell'abate P and Costi R: Stage III and metastatic lymph node ratio are the only independent prognostic factors in colorectal signet-ring cell carcinoma patients. Anticancer Res 40(12): 7127-7134, 2020. PMID: 33288612. DOI: 10.21873 /anticanres.14742

40 Ferri M, Lorenzon L, Onelli MR, La Torre M, Mercantini P, Virgilio E, Balducci G, Ruco L, Ziparo V and Pilozzi E: Lymph node ratio is a stronger prognostic factor than microsatellite instability in colorectal cancer patients: results from a 7 years follow-up study. Int J Surg 11(9): 1016-1021, 2013. PMID: 23747976. DOI: 10.1016/j.ijsu.2013.05.031

41 Pilozzi E, Ferri M, Onelli MR, Mercantini P, Corigliano N, Duranti E, Dionisi L, Felicioni F, Virgilio E, Ziparo V and Ruco L: Prognostic significance of $18 \mathrm{q} \mathrm{LOH}$ in sporadic colorectal carcinoma. Am Surg 77(1): 38-43, 2011. PMID: 21396303.

42 Frey MK, Kopparam RV, Ni Zhou Z, Fields JC, Buskwofie A, Carlson AD, Caputo T, Holcomb $\mathrm{K}$ and Chapman-Davis E: Prevalence of nonfounder BRCA1/2 mutations in Ashkenazi 
Jewish patients presenting for genetic testing at a hereditary breast and ovarian cancer center. Cancer 125(5): 690-697, 2019 PMID: 30480775. DOI: 10.1002/cncr.31856

43 Brenner RM, Kivity S, Kundel Y, Purim O, Peled N, Idelevich E, Lavrenkov K, Kovel S, Fenig E, Sulkes A and Brenner B: Ethnic variation in toxicity and outcome of adjuvant chemoradiation for gastric cancer in Israel. Anticancer Res 33(11): 5151-5157, 2013. PMID: 24222163.

44 Staiman VR, O'Toole KM, Rubin MA and Lowe FC: Giant malignant fibrous histiocytoma of the testis/spermatic cord: psychologic and possible etiologic complications of unethical Nazi medical experimentation. Urology 48(6): 939-943, 1996. PMID: 8973684. DOI: 10.1016/s0090-4295(96)00319-6

45 Zamstein O, Biderman A, Sherf M, David RB and Dreiher J: Cardiovascular morbidity and risk factors in Holocaust survivors in Israel. J Am Geriatr Soc 66(9): 1684-1691, 2018. PMID: 30183066. DOI: $10.1111 /$ jgs.15461

46 Svensson E, Grotmol T, Hoff G, Langmark F, Norstein J and Tretli S: Trends in colorectal cancer incidence in Norway by gender and anatomic site: an age-period-cohort analysis. Eur J Cancer Prev 11(5): 489-495, 2002. PMID: 12394247. DOI: 10.1097/00008469-200210000-00012

47 Svensson E, Møller B, Tretli S, Barlow L, Engholm G, Pukkala E, Rahu M, Tryggvadóttir L, Langmark F and Grotmol T: Early life events and later risk of colorectal cancer: age-period-cohort modelling in the Nordic countries and Estonia. Cancer Causes Control 16(3): 215-223, 2005. PMID: 15947873. DOI: 10.1007/s10552-004-3073-x

48 Nilsen TI and Vatten LJ: Adult height and risk of breast cancer: a possible effect of early nutrition. Br J Cancer 85(7): 959-961, 2001. PMID: 11592765. DOI: 10.1054/bjoc.2001.1946

49 Tretli S and Gaard M: Lifestyle changes during adolescence and risk of breast cancer: an ecologic study of the effect of World War II in Norway. Cancer Causes Control 7(5): 507-512, 1996. PMID: 8877047. DOI: 10.1007/BF00051882

50 Robsahm TE and Tretli S: Breast cancer incidence in food- $v s$ non-food-producing areas in Norway: possible beneficial effects of World War II. Br J Cancer 86(3): 362-366, 2002. PMID: 11875700. DOI: $10.1038 /$ sj.bjc. 6600084

51 Dirx MJ, van den Brandt PA, Goldbohm RA and Lumey LH: Energy restriction early in life and colon carcinoma risk: results of The Netherlands Cohort Study after 7.3 years of follow-up. Cancer 97(1): 46-55, 2003. PMID: 12491504. DOI: 10.1002/cncr.11052

52 Hughes LA, van den Brandt PA, de Bruïne AP, Wouters KA, Hulsmans S, Spiertz A, Goldbohm RA, de Goeij AF, Herman JG, Weijenberg MP and van Engeland M: Early life exposure to famine and colorectal cancer risk: a role for epigenetic mechanisms. PLoS One 4(11): e7951, 2009. PMID: 19956740. DOI: 10.1371/journal.pone.0007951

53 Dirx MJ, van den Brandt PA, Goldbohm RA and Lumey LH: Diet in adolescence and the risk of breast cancer: results of the Netherlands Cohort Study. Cancer Causes Control 10(3): 189199, 1999. PMID: 10454064. DOI: 10.1023/a:1008821524297
54 Dirx MJ, van den Brandt PA, Goldbohm RA and Lumey LH: Energy restriction in childhood and adolescence and risk of prostate cancer: results from the Netherlands Cohort Study. Am J Epidemiol 154(6): 530-537, 2001. PMID: 11549558. DOI: 10.1093/aje/154.6.530

55 Simons CC, van den Brandt PA, Stehouwer CD, van Engeland M and Weijenberg MP: Body size, physical activity, early-life energy restriction, and associations with methylated insulin-like growth factor-binding protein genes in colorectal cancer. Cancer Epidemiol Biomarkers Prev 23(9): 1852-1862, 2014. PMID: 24972776. DOI: 10.1158/1055-9965.EPI-13-1285

56 Elias SG, Peeters PH, Grobbee DE and van Noord PA: Breast cancer risk after caloric restriction during the 1944-1945 Dutch famine. J Natl Cancer Inst 96(7): 539-546, 2004. PMID: 15069116. DOI: 10.1093/jnci/djh087

57 Elias SG, Peeters PH, Grobbee DE and van Noord PA: The 1944-1945 Dutch famine and subsequent overall cancer incidence. Cancer Epidemiol Biomarkers Prev 14(8): 1981-1985, 2005. PMID: 16103448. DOI: 10.1158/1055-9965.EPI-04-0839

58 Fentiman IS, Allen DS and Ellison GT: The impact of the Occupation of Guernsey 1940-1945 on breast cancer risk factors and incidence. Int J Clin Pract 61(6): 937-943, 2007. PMID: 17504356. DOI: 10.1111/j.1742-1241.2007.01288.x

59 Koupil I, Plavinskaja S, Parfenova N, Shestov DB, Danziger PD and Vågerö D: Cancer mortality in women and men who survived the siege of Leningrad (1941-1944). Int J Cancer 124(6): 1416-1421, 2009. PMID: 19048620. DOI: 10.1002/ ijc. 24093

60 John Lyng, 72, Premier of Norway Briefly In '63. Available at: https://www.nytimes.com/1978/01/19/archives/john-lyng-72premier-of-norway-briefly-in-63.html [Last accessed on May 7 , 2021]

61 Beppe Fenoglio, da partigiano a scrittore. Available at: https://www.raicultura.it/letteratura/articoli/2018/12/BeppeFenoglio-da-partigiano-a-scrittore-cfb6f0b9-7ddc-4eaf-a 7f00132c9c62321.html [Last accessed on May 7, 2021]

62 Spellecy R and Busse K: The history of human subjects research and rationale for institutional board review oversight. Nutr Clin Pract, 2021. PMID: 33438782. DOI: 10.1002/ncp.10623

63 González-López E and Ríos-Cortés R: Visiting Holocaust-related sites with medical students as an aid in teaching medical ethics. Isr Med Assoc J 18(5): 257-260, 2016. PMID: 27430079.
Received April 4, 2021

Revised April 24, 2021

Accepted May 7, 2021 